\title{
Economic Growth and Public Expenditure: Country Specific Test of the Armey Curve Hypothesis In Nigeria And Ghana
}

\author{
Fredrick Onyebuchi Asogwa (Ph.D) \\ Department of Economics, \\ University of Nigeria, Nsukka
}

\author{
Ajibo Stephen Okwudili \\ Department of Accountancy, \\ Enugu State Polytechnic Iwollo, Enugu State \\ Musa Sherrif Urama \\ Department of Business Education, \\ Federal College of Education, Eha- Amufu, Enugu State
}

\begin{abstract}
The massive spending programs adopted by many countries around the world in response to the economic crisis of 2008 have drawn renewed attention to the role of government in an economy. Studies of the relationship between government size and economic growth in most countries of the world have come up with a wide range of estimates of the optimal or growth maximizing size of government, ranging between 15 to 30\% of Gross Domestic Product (GDP). These studies discovered the optimal size of government for the various countries using the theoretical framework of Armey Curve Hypothesis which theorized the existence of an optimal size of government that maximizes growth.Over the past year(s), government's aggregate expenditure has been less than its aggregate expenditure the present year(s) in Nigeria and Ghana. This has made the government size of these economies big enough to command a significant economic growth in these countries, but this is not the case in these countries. This work adopted a concave parabolic model from the origin which portrays the Armey curve model to empirically validate not only the existence of Armey curve hypothesis but also to fond the optimizing government expenditure of Ghana and Nigeria, using time series data from 1981 to 2016. The result showed that Armey curve hypothesis exists both in Nigeria and Ghana. However, the result shows a strong statistical influence of Armey hypothesis in Nigeria than in Ghana. In line with the main objective of the study, the optimal size of the government was found to be $12.5 \%$ and $7.3 \%$ of the gross domestic product in Nigeria and Ghana respectively. The implication is that Government of Nigeria and Ghana should spend $12.5 \%$ and $7.3 \%$ respectively, of her gross domestic product (GDP) to attain the optimal growth of $\$ 3$ Trillion Naira and \&4.3 million respectively. The researcher recommends that these governments should cut down their expenditure to the optimizing size of their governments so as to grow effectively and efficiently which is a macroeconomic goal of every economy.
\end{abstract}

Keywords: Public Sector, Government Expenditure, Government Size, Economic Growth, Ghana, Nigeria

\section{INTRODUCTION}

There is an ongoing debate in public sector economics on the optimum size of government within an economy. The first notion shows that the bigger the of size government, the larger the financial burden (and hence, reduced economic growth) it imposes on the economy. Advocates of bigger government argue that government programmes provide valuable public goods such as education, law and order, justice, and infrastructure, which the private sector 
cannot efficiently provide. This argument claims that increases in government spending can bolster economic growth by increasing the disposable incomes of the people and hence, their purchasing power (Mitchell, 2005). The second indicates that the economy becomes better off when managed by the private sector (Amoafo, 2011). Proponents of smaller government, however, have the opposite view. They explained that bigger government stifles the spirit of enterprise, and impact negatively on economic growth through government inefficiencies, excess burden of taxation, and distortion of the incentive system.

These recent arguments were anchored in the earlier debate between the Classical economists and the Keynesians on the role and size of state activity. The Classical economist had predominantly maintained their doctrine of minimum government intervention in economic affairs of the nation, in the 19th Century. They maintained that the economy should be driven by an invisible hand (the Market forces) with mild government intervention to enforce laws and contract. the validity of the Classical Economics' doctrine was questioned as unemployment soared higher without market forces correcting the abnormally during the inception of the "Great Depression" of the 30s'. This gave rise to the doctrine of the Keynesians which identified inadequate demand as the major cause of the crisis and hence suggested the intervention of the government in the economy as the only way out (Garrett and Rhines, 2006). Since the emergence of this view, the size of the government in the global economies grew tremendously with severe governments' failures which gave credence to the debate for an optimal size of government.

This debate has created diverse, conflicting, and inconclusive empirical evidence by different researchers. Barro (1990), Rubinson (1977), Ram (1986), Aschauer (1989), Alexiou (2007), Jiranyakul (2007) discoverered that increase in spending by the government raises marginal productivity of capital which raises growth rate. Landau (1983), Grier and Tullock (1989), Guseh (1997), Henrekson (2003), Udah (2010) found a negative relationship between increase in government size and economic growth. This implies that growth in the size of government hampers the economic well-being of the citizens.

The economies of Nigeria and Ghana have significant governments participation and hence not immune to this dilemma. Nigeria had different political regimes, different government structures and spending pattern with peculiar policy thrusts. In Ghana, almost the same political environment of regimes and counter regimes were obtained. The growth rates of the Gross Domestic Product (GDP) and Government Expenditure of the countries are shown in table 1.

Table 1: The growth rates of the Gross Domestic Product (GDP) and Government Expenditure in Nigeria and Ghana

\begin{tabular}{|l|c|c|c|c|}
\hline year & GGE $(\%$ of GDP) & NGE $(\%$ of GDP) & GGDP growth & NGDP growth \\
\hline 1981 & 8.79024041 & 14.6608884 & -3.503066947 & -13.1279 \\
\hline 1985 & 9.398393228 & 12.73175526 & 5.091617273 & 8.32283 \\
\hline 1990 & 9.311528428 & 4.9644385 & 3.328817883 & 12.76601 \\
\hline 1995 & 12.07348066 & 12.08512444 & 4.11241904 & -0.30747 \\
\hline 2000 & 10.17161587 & 8.342579909 & 3.700000115 & 5.318093 \\
\hline 2005 & 15.30816526 & 6.807475773 & 5.900003953 & 3.444667 \\
\hline 2010 & 10.35530523 & 8.711383627 & 7.899740293 & 7.839739 \\
\hline 2015 & 19.15905628 & 6.688120383 & 3.917221644 & 2.652694 \\
\hline
\end{tabular}

Source: Worldbank Development Indicator WDI (2016) 
The growth rate of GDP in Ghana in 1981 was $-3,5 \%$ while its government expenditure stood at 8.79\%. Government expenditure continued to increase in Ghana from 9.4\% in 1985 to $19.2 \%$ in 2015. The reverse was the case in the growth of GDP in Ghana which stood at 5.09\% in 1985 and decreased drastically to 3,9\% in 2015. Government expenditure in Nigeria decreased from $14.7 \%$ in 1981 to $12.7 \%$ and $4 \%$ in 1985 and 1990 respectively. In 1995, Nigeria's expenditure went up to $12.1 \%$ and later dropped to $6.7 \%$ in 2015. Nigeria's GDP growth which was $-13.1 \%$ in 1981 rose to $12.8 \%$ in 1990 and later decreased to $2.65 \%$ in 2015 . The relationship between GDP growth and government expenditure growth in Ghana is shown with the aid of figure 1

Figur 1: GDP growth and government expenditure growth in Ghana

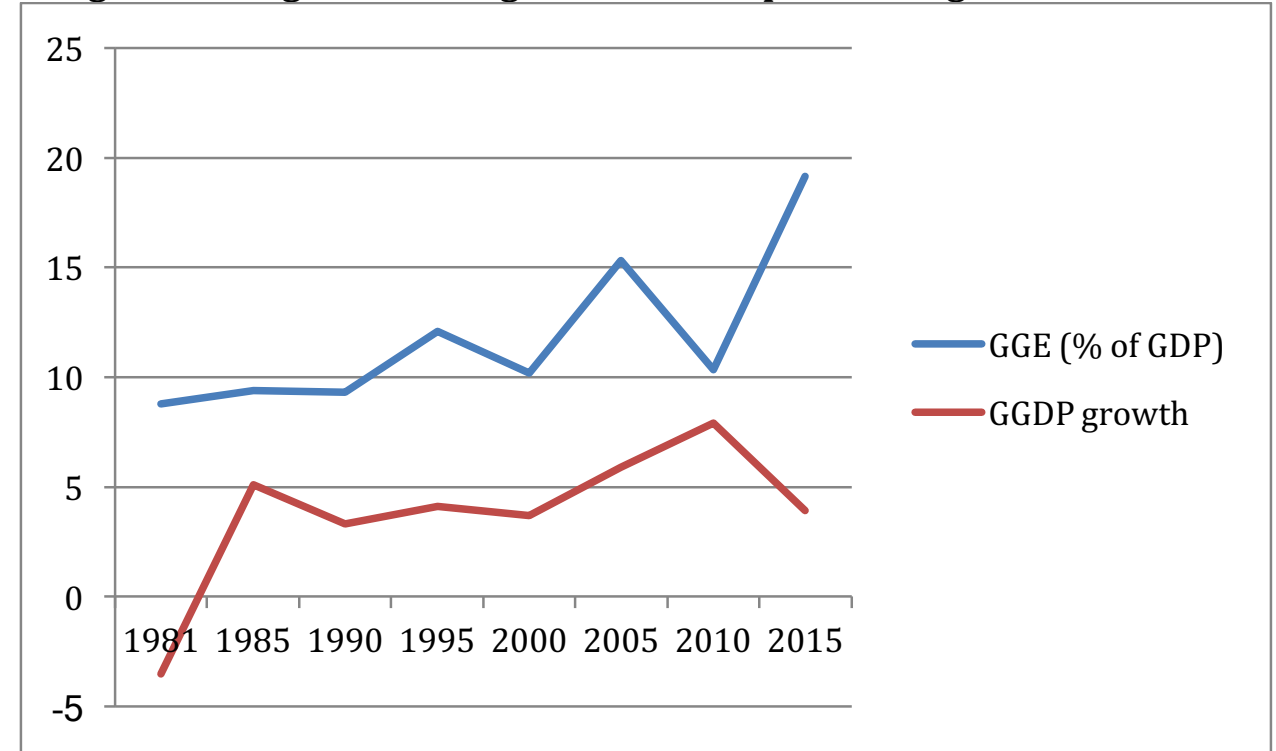

There was a positive relationship between GDP growth in Ghana and government expenditure from 1981 to 2010 and a negative relationship from 2010 to 2015 The GDP growth rate in Ghana is far lower than the expenditure growth. In Nigeria, the GDP growth rate and government expenditure interaction is shown in figure 2.

Figure 2: GDP growth rate and government expenditure growth rate interaction in Nigeria

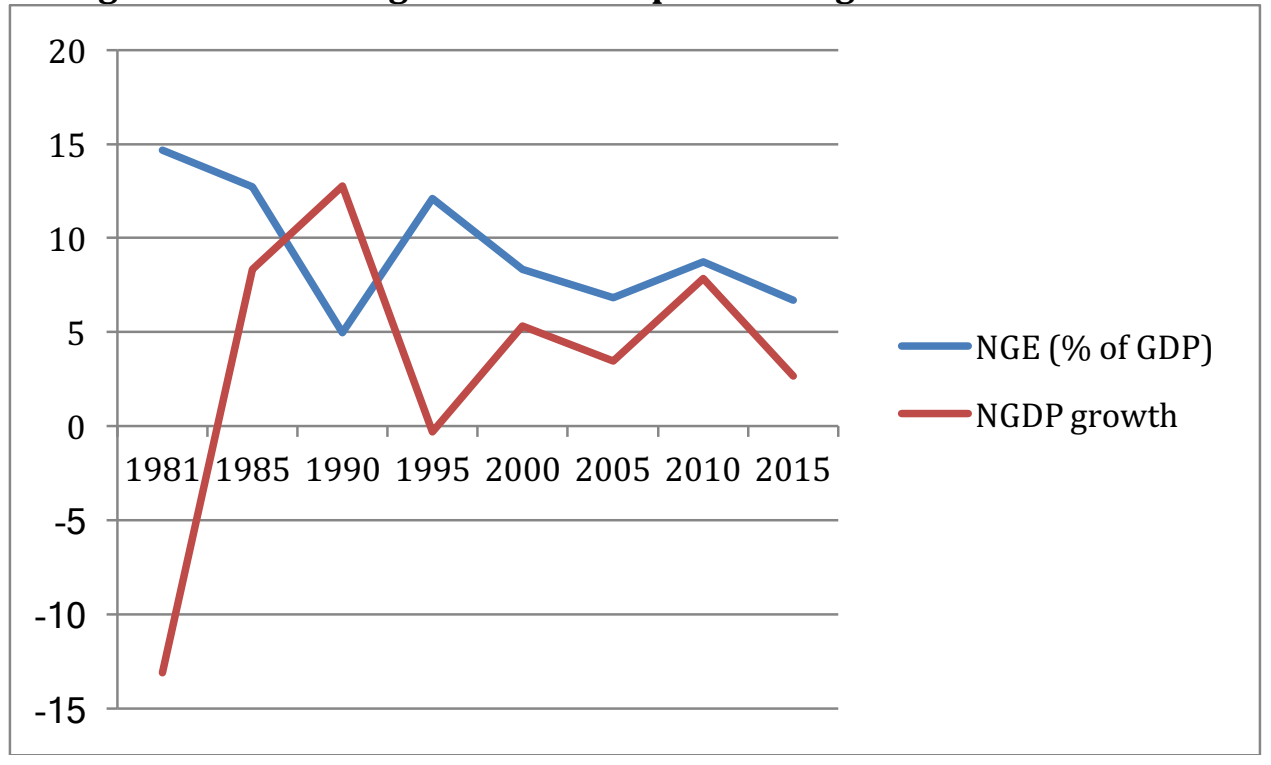

Nigeria's expenditure growth and GDP growth had been in inverse relationship from 1981 to 2000 and in positive relationship between 2000 and 2015 except in very few places. 
From the discussion on the total public expenditure of Nigeria and Ghana economies, it is evident that there has been a significant increase in the participation of the government in the economy with mild economic growth in the various years. In view of this, this paper investigated the existence of the Armey curve hypothesis in Nigeria and Ghana to find out if Armey curve hypothesis is empirically validated in Nigeria and Ghana. It also found the optimizing size of governments and the yielding Gross Domestic product (output) of these optimizing sizes of the governments in Nigeria and Ghana.

\section{LITERATURE}

Adolph Wagner formulated the law of increasing state activity commonly referred to as Wagner's law in 1883. The theory emphasizes economic growth as the fundamental determinant of public sector growth. The law states that as per capita income in a country grows, the relative size of the public sector also grows. Wagner recognized three functions of the state: Providing administration and protection; ensuring stability; and providing for the economic and social welfare of the society as a whole. (Henrekson, 1993 in Verma and Arora,2010).

Peacock and Wiseman displacement effect shows that government expenditure depends broadly on revenue raised by taxation and that taxation sets a constraint on government expenditure. This theory explains the social problems such as famine or national crises which lead to an increase in public expenditure. It maintains the view government expenditure will remain at its new level after the crisis as the tax payers would accept them as part of life (Black et al, 1999).

Government expenditure tends to increase when an economy develops from a subsistence economy to an industrialized economy. Musgrave and Rostow's model points out that government may have to participate actively to provide basic infrastructures that would make the environment conducive for economic development at the first stage, supplies investment goods at the middle stage and provides public services such as education, health, pipe borne water, and transport at the final stage through budgetary allocation.

Government expenditure may also Increase disproportionately because of an increase in the price of inputs used by the public sector relative to those employed in the private sector as indicated by the Baumol's Unbalanced productivity growth theory in 1967. He divided the economy into progressive sector, which is made up of technologically progressive activities such as innovation, capital formation, and economies of scale, all of which contribute towards a rise in the level of output and the non-progressive sector which is characterized by the accommodation of sporadic changes in productivity. Brown and Jackson (1990) sees increase in government expenditure as a result of changes in the sizes of the population and its structure, and the quality of goods demanded by the median voter.

Barro (1991) in a cross country study of 98 countries for a period spanning from 1960 to 1985, using average annual growth rates in real per capita GDP and the ratio of real government consumption to real GDP concluded that the relationship between economic growth and government consumption is negative and insignificant. Hsieh and Lai (1994) revealed the inconsistency in establishing that there is a positive or a negative relationship between government size and economic growth. Other work that found positive relationship between government expenditure and economic growth are Alexiou (2007), Jiranyankul (2007), Herath (2009) 
Conte and Darrat (1988) investigated the causal direction between public sector growth and real economic growth rates for the OECD countries and found that government expenditure growth has had mixed effects on economic growth in the various countries, positive for some countries and negative for others.

Guseh (1997), Knoop (1999) and Ramayandi (2003) found that a reduction in the size of the government would have an adverse impact on economic growth and welfare. Yamamura (2008), in an attempt to examine how the relationship between government size and life satisfaction changes using the OLS and 2SLS, discovered that government size has a detrimental effect on life satisfaction when government size impedes economic growth in the economic development stage. However, this effect clearly decreases when government size is not associated with economic growth in the developed stage.

Taban (2010) used the Barro's endogenous growth model to re-investigate the government spending-economic growth nexus for the Turkish economy using bounds testing approach and MWALD Granger causality test. A bidirectional causality between the total government spending and economic growth, whereas no statistically significant relationship between the share of government consumption spending to GDP and economic growth.

Chen and Kim (2011) employed the quantile regression methodology to investigate the relationship between government size and economic growth using a panel data set for 24 OECD countries. Their findings was that the magnitude of the effect of government size on economic growth varies through the quantile; when economic growth is low, increasing the size of the government may have a positive effect and stimulate economic growth. However, as the economic growth increases, government size will have a negative effect on economic growth. Other researchers of the same view are Mehrara and Keikha (2012)

Vedder and Gallaway (1998) found that the optimal size of federal government spending based on the Armey curve in the United States in the period 1947-1997 was 17.45 percent of Gross Domestic Product while. Peden (1991) estimated the optimal size of United States government as 20 percent of Gross Domestic Product. Scully (1994) realize similar result while estimating the optimal growth-maximizing average rate for federal, state, and local government taxes combined to be between 21.5 percent and 22.9 percent of GNP in the United States between 1929 and 1989. Also, Chao and Gruber (1998) estimated that in the period 1929 - 1996, optimal size of government spending in Canada was about 27 percent.

Chen and Lee (2005) in order to find the threshold effects employed Hansen (2000) sampling splitting and threshold estimation technique to test whether the Armey curve exists in Taiwan, allowing for endogenous government size thresholds. The result indicates that a non-linear relationship of the Armey curve exists in Taiwan. Mustacu and Milos (2009) tried to establish the optimal size of the public sector for European Union member states. They discovered 30.42 percent of GDP to be the optimal public sector size for EU-15 countries and 27. 46 percent of GDP for EU-12 countries. Pevcin (2005) using Armey Curve as a tool in his study showed that the optimal size of government in the sample of 12 European countries is approximately between 36 and 42 percent of GDP.

Vaziri et al (2011) verified the existence of Armey curve in Pakistan and Iran Economies. Their findings indicate the existence of a non-linear Armey curve relationship between government size and economic growth in Iran and Pakistan economies. 
Richard (2009) adopted a Barro-type production function to chart out a growth model that accounts for the productivity of government spending and also adopts Wagner's hypothesis to account for endogenity resulting from fiscal expansion. The result shows that government expenditure was unproductive in Nigeria. Okpara and Nwaoha (2010) examine the relationship between government expenditure, money supply, prices and output in Nigeria and found out that government expenditure was also unproductive in Nigeria. Loto (2010) investigated the growth effect of government expenditure on economic growth in Nigeria over the period of 1980 to 2008 and found that expenditure on agriculture, education were negatively related to economic growth while expenditure on health, national security, transportation, and communication were positively related. Nurudeen and Usman (2010), Taiwo and Abayomi (2011), Ditimi et al (2011), Nasiru (2012) Ekeocha and Oduh (2012) conducted a study to determine the optimal size of federal government in Nigeria. The result of the study suggests that the optimal level of federal government expenditure is approximately 23 percent.

\section{THE MODEL}

In order to test the relationship between the general government expenditure and economic growth that is theoretically characterized by an inverted $U$ - shaped Curve (as proposed by Armey, 1996), we use a concave parabolic (quadratic) function from the origin (without intercept) which posits the relationship that runs from government expenditure squared, and government expenditure, to economic growth. Given the concave nature of the Armey curve, we are expectant that the coefficient of the highest power of the parabolic model be negative as to show and prove the concavity of the Armey curve (Concave Parabolic) Model.

The broad objective of this work is to test empirically the existence of Armey curve hypothesis in Ghana and Nigeria. Hence, we have the relations:

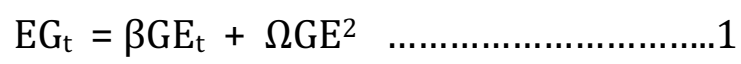

Where

$\mathrm{EG}=$ Economic Growth

$\mathrm{GE}=$ Government Expenditure

$\mathrm{GE}^{2}=$ the square value of government Expenditure

To find the optimal (Relative Maxima) or Relative Minima of a quadratic function, Calculus Method is applied by taking the critical point and equate it to zero, so as to find the optimizing size of the government and thus produce the optimal economic growth.

ImposIing the concavity axiom in equation 1

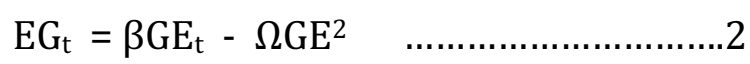

Finding the critical value of the function and setting it equal to zero

$$
\begin{gathered}
\frac{\partial E G_{t}}{\partial G E_{t}}=\beta-2 \gamma G E_{t}=0 \\
G E_{t}^{*}=\frac{\beta}{2 \gamma}= \pm \frac{a}{2 b} \ldots \ldots \ldots \ldots \ldots \ldots \ldots \ldots \ldots \ldots . \cdots \cdots \cdots \cdots \cdots
\end{gathered}
$$




\section{THE RESULTS}

The results of the parabolic function specified for Nigeria and Ghana are illustrated with the aid of table 1.

TABLE 1

Regression Result

\begin{tabular}{|l|c|c|c|c|}
\hline Country & Variable & coefficient & T-stat & Prob \\
\hline Nigeria & Get & 0.8370441 & 3.93 & 0.000 \\
\hline & $\mathrm{GE}^{2 \mathrm{t}}$ & -0.0334803 & -3.39 & 0.002 \\
\hline Ghana & Get & 1.52565 & 2.87 & 0.007 \\
\hline & $\mathrm{GE}^{2 \mathrm{t}}$ & -0.1052238 & -1.30 & 0.202 \\
\hline
\end{tabular}

\section{Source: stata12 computation}

To examine the existence of Armey curve hypothesis in Nigerian and Ghanaian economies the following were done.

NIGERIA: $E G N=0.8370441$ GEG -0.0334803 SQGEG

GHANA: $E G G=1.52565 G E N-0.1052238$ SQGEN

From the parabolic models of Nigeria and Ghana shown above. It is evident and therefore empirically proven that Armey Curve hypothesis exit in Nigeria and Ghana. This is inferred by the negative sign of the squared values of government expenditure in both countries, hence a concave parabolic model.

Moreover, it is important to note that this Armey Curve in Nigeria is statistically significant as its values are all absolutely greater than zero. On the other hand, though it exists in Ghana but it is therefore not statistically significant as the $t$-value of $\mathrm{GE}^{2} \mathrm{t}$ is absolutely less than 2 .

To find the optimizing size of these governments (Relative Maxima), we under take the steps in chapter three.

\section{Step1: state the concave parabolic model}

Nigeria GHANA: EGG $=0.8370441 \mathrm{GEG}-0.0334803 \mathrm{GEG}^{2}$

Ghana NIGERIA: EGN= 1.52565GEN - 0.1052238GEN ${ }^{2}$

Step2: take the critical point of the function (first derivative) and set equal to zero

$\frac{\triangle E G t}{\Delta G E t}=0$

Ghana Nigeria

$\frac{\Delta E G t}{\Delta G E t}=1.52565-0.2104476 \mathrm{GEN}$

$0=1.52565-0.2104476 \mathrm{GEN}$

GEN $=1.52565 / 0.2104476$

$\mathrm{GEN}==7.25(3 . \mathrm{s.f})$

Nigeria Ghana:

$\frac{\Delta E G t}{\Delta G E t}==0.8370441 \mathrm{GEG}-0.0669606 \mathrm{GEG}$

$0=0.8370441 \mathrm{GEG}-0.0669606 \mathrm{GEG}$

$\mathrm{GEN}=0.8370441 \mathrm{GEG} / 0.0669606$

Get $=12.5$ (3.s.f) 
In summary of the optimizing government size results, recall that the government expenditure used in this work are percentages of the government expenditure to its Gross Domestic product (GDP). To maximize the economic growth of Nigeria, the government of Nigeria should spend $12.5 \%$ of its Gross Domestic product (GDP) while the government of Ghana should spend $7.3 \%$ of its Gross Domestic product (GDP). When this is done, optimal economic growth of both economies are assured.

To ascertain the yielding Gross Domestic product (output) of these optimizing sizes of the government, we substitute these optimizing size of the government back in their respective.

$$
\begin{aligned}
& \text { GHANA: } E G G=0.8370441 G^{*}{ }^{*}-0.0334803 G^{*}{ }^{* 2} \\
& \text { NIGERIA: } E G N=1.52565 G^{*}{ }^{*}-0.1052238 \text { SQGEN }^{* 2}
\end{aligned}
$$

That is: $\mathrm{EGG}=0.8370441(7.3)-0.0334803(7.3)^{2}=4.33$

$\mathrm{EGN}=1.52565(12.5)^{*}-0.1052238 \mathrm{~S}(12.5)^{* 2}=2.63$

\section{SUMMARY AND POLICY RECOMMENDATIONS}

In nutshell, the government aggregate expenditure should not be sentimental but objective based both in Nigeria and Ghana. Moreover, being objective based is both a necessary condition to optimizing the output of the economies. Above the objectivity is a financial mandate constraint. If every government has a particular amount to spend per annum, it will guide it through allocation funds for projects. Even though there might be many objective based projects to carry out in a year, the mandate of a limit of what to spend will assist the government in finding out more impressing and vital decisions to undertake, thus ranking the objective based projects in a scale of necessity and vitality. Some governments therefore also advocates austerity measures, to cut down public spending drastically and still achieve economic growth.

In recommendation, the governments of Nigeria and Ghana should stick to this optimizing size of the government, enforce it and maintain a suitable environment which will produce a great or highest gross domestic product for these countries. The institutions in these economies should also be made strong and not weak to stand against the deficiencies inherent in thepublic sector and still give room for the private sectors to execute their activities as the government regulates, maintain law and order and enforces property rights

\section{References}

Abayomi, S. T. and Kehinde, K. A., 2011. Government Expenditure in Nigeria: A Sine Qua Non for Economic Growth and Development. JORIND, Vol. 9, No. 2.

Abayomi, S. T. and Kehinde, K. A., 2011. Government Expenditure in Nigeria: A Sine Qua Non for Economic Growth and Development. JORIND, Vol. 9, No. 2.

Abounoori, E. and Nademi, Y., 2010. Government Size, Threshold and Economic Growth in Iran. International Journal of Business and Development Studies, Vol. 2, No. 1, pp. 95108.

Abounoori, E. and Nademi, Y., 2010. Government Size, Threshold and Economic Growth in Iran. International Journal of Business and Development Studies, Vol. 2, No. 1, pp. 95108.

Abrams, A. B., and Wang, S., 1999. The Effect of Government Size on the Steady - State Unemployment Rate: A Structural Error Correction Model. University of Delaware, Department of Economics Working Papers, No. 06-05.

Abrams, A. B., and Wang, S., 1999. The Effect of Government Size on the Steady - State Unemployment Rate: A Structural Error Correction Model. University of Delaware, Department of Economics Working Papers, No. 06-05.

Adofu, I., Abula, M., and Agama, J. E., 2012. The Effects of Government Budgetary Allocation to Agricultural Output in Nigeria. Sky Journal of Agricultural Research, Vol. 1, No. 1, pp. 1-5. 
Asogwa, F. O., Okwudili, A. S., \& Urama, M. S. (2019). Economic Growth and Public Expenditure: Country Specific Test of the Armey Curve Hypothesis In Nigeria And Ghana. Advances in Social Sciences Research Journal, 6(1) 498-509.

Adofu, I., Abula, M., and Agama, J. E., 2012. The Effects of Government Budgetary Allocation to Agricultural Output in Nigeria. Sky Journal of Agricultural Research, Vol. 1, No. 1, pp. 1-5.

Afonso, A. and Furceri, D., 2008. Government Size, Composition, Volatility, and Economic Growth. European Central Bank Working Paper Series No 849.

Afonso, A. and Furceri, D., 2008. Government Size, Composition, Volatility, and Economic Growth. European Central Bank Working Paper Series No 849.

Aladejare A. S., 2013. Government spending and economic growth: Evidence from Nigeria. Munich personal RePEc Archive

Aladejare A. S., 2013. Government spending and economic growth: Evidence from Nigeria. Munich personal RePEc Archive.

Alexiou, C., 2009. Government Spending and Economic Growth: Econometric Evidence from the South Eastern Europe. Journal of Economic and Social Research, Vol. 11, No 1, pp. 1 -16.

Alexiou, C., 2009. Government Spending and Economic Growth: Econometric Evidence from the South Eastern Europe. Journal of Economic and Social Research, Vol. 11, No 1, pp. 1 -16.

Aly, H. and Strazicich, M., 2000. Is Government Size Optimal in the Gulf Countries of the Middle East? An Empirical Investigation. International Review of Applied Economics, Vol. 14, No. 4.

Aly, H. and Strazicich, M., 2000. Is Government Size Optimal in the Gulf Countries of the Middle East? An Empirical Investigation. International Review of Applied Economics, Vol. 14, No. 4.

Amoafo, S., 2011. Government Spending - It's Impact on Economic Performance. [Online] Modern Ghana PLC. Available at: <http://www.modernghana.com/news/322454/1/.

Amoafo, S., 2011. Government Spending - It's Impact on Economic Performance. [Online] Modern Ghana PLC. Available at: <http://www.modernghana.com/news/322454/1/.

Armey, R., 1995. The Freedom Revolution. Washington DC: Rognery Publishing Co.

Armey, R., 1995. The Freedom Revolution. Washington DC: Rognery Publishing Co.

Ashauer, D. A., 1989. Is Public Expenditure Productive? Journal of Monetary Economics, Vol. 23, pp. 177 - 200.

Ashauer, D. A., 1989. Is Public Expenditure Productive? Journal of Monetary Economics, Vol. 23, pp.177- 200.

Barro, R. J., 1990. Government Spending in a Simple Model of Endogenous Growth. Journal of Political Economy, Vol. 98, No. 5, pp. $103-125$.

Barro, R. J., 1990. Government Spending in a Simple Model of Endogenous Growth. Journal of Political Economy, Vol. 98, No. 5, pp. $103-125$.

Barro, R., 1989. A Cross - Country Study of Growth, Saving and Government. NBER Working Paper No 2855.

Barro, R., 1989. A Cross - Country Study of Growth, Saving and Government. NBER Working Paper No 2855.

Bergh, A. and Henrekson, M., 2010. Government Size and Implications for Economic Growth. Washington DC: American Enterprise Institute Press.

Bergh, A. and Henrekson, M., 2010. Government Size and Implications for Economic Growth. Washington DC: American Enterprise Institute Press.

Bergh, A. and Henrekson, M., 2011. Government Size and Economic Growth: A Survey and Interpretation of the Evidence. IFN Working Paper No. 858.

Bergh, A. and Henrekson, M., 2011. Government Size and Economic Growth: A Survey and Interpretation of the Evidence. IFN Working Paper No. 858.

Black, J., 2003. Dictionary of Economics. New York: Oxford University Press Inc.

Black, P.A., Calitz, E., Steenekamp, T.J., and Associates, 1999. Public Economics for South African Students,

Southern Africa: cape Town Oxford University Press.

Blaxter, L., Hughes, C., and Tight, M., 2006. How to Research, Third Edition. London: Mc Graw-Hill Bredemeier C., 2010. Imperfect information and the Meltzer - Richard Hypothesis, Ruhr Economic Paper No. 213.

CBN, Statement of Account (2003).

Chao, J. and Grubel, H., 1998. Optimal Levels of Spending and Taxation in Canada. 
Chen S., Chen C., and Kim, Y., 2011. Economic Growth and Government Size in OECD Countries: New Evidence from the Quantile Regression Approach. Economics Bulletin, Vol. 31, No.1.

Chen, S. T. and Lee, C. C., 2005. Government Size and Economic growth in Taiwan: A Threshold Regression Approach. Journal of Policy Modeling, Vol. 27, No. 9, 1051-1066.

Chobanov, D., and Mladenova, A., 2009. What is the Optimum Size of Government? Institute for Market Economics, Bulgaria.

Conte, M. A. and Darrat, F. A., 1988. Economic Growth and the Expanding Public Sector: A Re Examination, Review of Economics and Statistics, Vol. 70, No. 2.

Cookey, A. E., 2010. Does government expenditure yield greater dividends in Democracies? A comparative analysis of military and civilian Regimes in Nigeria.

Cooray, A. V., 2009. Government Expenditure, Governance, and Economic Growth. University of Wollongong Research Online.

Dash, K. R. and Sharma, C., 2008. Government Expenditure and Economic Growth: Evidence from India. India: The Icfai University Press Co.

Ditimi, A., Adebayo, R. A., and Philip, N., 2011. Components of Government Spending and Economic Growth in Nigeria: An Error Correction Modeling. Journal of Sustainable Agriculture, Vo. 5, No 2.

Dizaji, F. S., 2012. Exports, Government Size and Economic Growth (Evidence from Iran as a Developing Oil Export Based Economy) Institute of Social Studies Working Paper No. 535.

Ekeocha, P. C., and Moses, O., 2012. Determining the Optimal Size of Federal Government in Nigeria: An Empirical Investigation.

Ekinci, A., 2011. What is the Optimum Size of Government: A Suggestion? International Journal of Economics and Financial Studies, Vol. 3, No. 11.

Forte, F., and Magazzino C., 2011. Optimal Size of Government and Economic Growth in EU countries.

Garrett, T. A. and Rhine, R. M., 2006. On the Size and Growth of Government. Federal Reserve Bank of St. Louis Review, Vol. 88, No. 1.

Grier, K. B. and Tullock, G., 1989. An Empirical Analysis of Cross - National Economic Growth, 1951 - 1980. Journal of Monetary Economics, No. 24, pp. 259 - 276.

Grossman, P., 1988. Growth in Government and Economic Growth: the Australia Economics Papers 27: 33 - 45.

Gujarati, D. N., and Porter, D. C., 2009. Basic Econometrics, Fifth Edition. Singapore: Mc Graw Hill Companies inc.

Guseh, J. S. and Oritsejafor, E., 2007. Government Size, Political Freedom, and Economic Growth in Nigeria, 1960 2000. Journal of Third World Studies, Vol. XXIV, No. 1.

Guseh, J. S., 1997. Government Size and Economic Growth in Developing Countries: A Political Economy Framework. North Carolina: Shaw University Press Co.

Herath, S., 2010. The Size of the Government and Economic Growth: An Empirical Study of Sri Lanka. Institute for the Environment and Regional Development.

Hsieh, E. and Lai, K. S., 1994. Government Spending and Economic Growth: The G - 7 Experiences. USA: California State University Press Co.

http://en.wikipedia.org/wiki/Capital_expenditure [Accessed 20th December, 2012].

Indriawan, Y. and Muhyiddi, 2007. Government Size and Growth: Evidence from Indonesia. Journal of Development Planning, Edition 03 - 04/ Tahun XII, 2007.

Jiranyakul, K., 2007. The Relation Between Government Expenditures and Economic Growth in Thailand. National Institute of Development Administration, Thailand TantatapeBrahmasrene, Purdue University North Central.

Kerry - Ann, A., Denny L. and Winston, M., 2004. An Assessment of the Growth - Enhancing Size of Government in the Caribbean. Applied Econometric and International Development, Vol. 4, No 3.

Keynes J. M., 1936. The General Theory of Employment, Interest and Money, London, Macmillan for the Royal Economic Society.

Knoop, T. A., 1999. Growth, Welfare and the Size of Government. Journal of Economic Enquiry, Vol. 37, No. 1, pp. $103-119$ 
Asogwa, F. O., Okwudili, A. S., \& Urama, M. S. (2019). Economic Growth and Public Expenditure: Country Specific Test of the Armey Curve Hypothesis In Nigeria And Ghana. Advances in Social Sciences Research Journal, 6(1) 498-509.

Koutsoyiannis, A., 1977. Theory of Econometrics, 2nd Edition. London: Macmillan Press.

Kustepeli, Y., 2005. The Relationship between Government Size and Economic Growth: Evidence from a Panel Data Analysis. Turkey: DozukEylul University Press Co.

Kweka, J. P. and Morrissey 0., 2009. Government Spending and Economic Growth in Tanzania, 1965 - 1996. United Kingdom: University of Nottingham Press Co.

Landau, D., 1983. Government Expenditure and Economic Growth: A Cross Country Study. Southern Economic Journal, Vol. 49, pp. 783 - 792.

Lane, J., 2000. The Public Sector: Concepts, Models and Approaches. London: Sage.

Lee, B. S. and Lin, S., 1994. Government Size, Demographic Changes and Economic Growth. International Economic Journal, Vol. 8, No. 1.

Lizardo, R. and Mollick, A. V., 2009. Can Latin America Prosper by Reducing the Size of Government? Cato Journal, Vol. 29, No 2 .

Loto, M. A., 2011. Impact of Government Sectoral Expenditure on Economic Growth. Journal of Economics and International Finance, Vol. 3, No 11, pp. $646-652$.

Madalla, G., 1995. Introduction to Econometrics. New York: Macmillan Publishing Company.

Madueme, S. I., 2010. Fundamental Rules in Social Science Research Methodology. Enugu: Jolyn Publishers, Nsukka.

Masaviru, W. and Mudaki, J., 2012. Does the Composition of Public Expenditure Matter to Economic Growth for Kenya? Economics and sustainable Development, Vol. 3, No 3.

Mba I. N., and Olugu, K. N., 2011. Increasing Size of Government: Implication for Output Growth in Nigeria. Social Science Research Network.

Mehdi, S. and Shoorekchali, J. M., 2012. The Impact of Government Size on Economic Growth: A Case Study in Italy. Australian Journal of Basic and Applied Sciences, Vol. 6, No 9, pp. 616 - 621.

Mehrara, M. and Keikha, A., 2012. Government Size and Economic Growth in Iran. International Journal Research, Vol. 3, No. 2, pp. $52-60$.

Mutascur, M., and Milos, M., 2009. Optimal Size of Government Spending. The Case of European Union Member States. AnnalesUniversitatisApulensis Series Oeconomica, Vol. 1, No 11

Nasiru, I., 2012. Government Expenditure and Economic Growth in Nigeria: Cointegration Analysis and Causality Testing. Academic Research International Journal, Vol. 2, No 3.

Nassiri, M., Mohajerani, Y., and Babace, N., 2011. The Optimal Government Size in Iran Agricultural Sector. American - Eurasian Journal of Sustainable Agriculture, Vol. 5, No 2.

Nurudeen, A. and Usman, A., 2010. Government Expenditure and Economic Growth in Nigeria, 1970 - 2008; A Disaggregated Analysis. Business and Economics Journal, Vol. 2010: BEJ 4.

Nworji I., Okwu A., Obuwuru T., and Nworji L, 2012. Effects of public expenditure on economic growth in Nigeria: A disaggregated time series analysis. International Journal of management sciences and business research, 2012, Vol 1, No 7.

Obilonu A., 2013. Government spending and economic growth in Nigeria. An Unpublished M.Sc. Thesis.

Okpara, G. C., and Nwaoha, W. C., 2010. Government Expenditure, Money Supply, Prices, and Output Relationship in Nigeria: An Econometric Analysis. International Research Journal of Finance and Economics, 54, 125 - 132.

Peden, E. A., 1991. Productivity in the United States and its Relationship to Government Activity: An Analysis of 57 Years, 1929 - 1986. Public Choice, No. 69, 153 - 173.

Pevcin, P., 2005. Does Optimal Size of Government Exist?

Ram, R., 1986. Government Size and Economic Growth: A New Framework and Some Evidence from Cross Section and Time - Series. American Economic Review, Vol. 76, 191 - 203.

Ramayandi, A., 2003. Economic Growth and Government Size in Indonesia: Some Lessons for the Local Authorities. Working Papers in Economics and Development Studies No. 200302.

Richard, 0. O., 2009. A Bayesian Analysis of Government Expenditure in Nigeria. Munch Personal RePEc Archive Working Paper, No 18244. 
Rubinson, R., 1977. Dependency, Government Revenue, and Economic Growth, 1955 - 70. Studies in Comparative International Development, Vol. 12, 3 - 28.

Safdari, M., Mahmoodi, M., and Mahmoodi, E., 2012. Government Expenditure and Economic Growth: Panel Evidence from Asian Countries. Life Science Journal, Vol. 9, No. 2.

Samimi, A. J., Nademi, Y., and Zobeiri, H., 2010. Government Size and Economic Growth: A Threshold Regression Approach in Selected Islamic Countries. Australian Journal of Basic and Applied Sciences, Vol. 4, No. 8.

Scully, G. W., 1994. What is the Optimal Size of Government in the United States? NCPA Policy Report No. 188. Dallas: National Centre for Policy Analysis.

Sevitenyi, L. N., 2012. Government Expenditure and Economic Growth in Nigeria: An Empirical Investigation (1961 - 2009). The Journal of Economic Analysis, Vol. III, No.1, 38 - 51.

Siddiqui, M. and Malik, A., 2011. Impact of Government Expenditure on Income Distribution: A theoretical Analysis in the Case of Pakistan. International Journal of Economics and Management Sciences, Vol. 1, No. 1, 87 - 92.

Taban, S., 2010. An Examination of the Government Spending and Economic Growth Nexus for Turkey Using the Bound Test Approach. International Research Journal of Finance and Economics, No 45.

Taiwo, M. and Abayomi, T., 2011. Government Expenditure and Economic Development Empirical Evidence from Nigeria. European Journal of Business and Management, Vol. 3, No 9.

Udah, E., 2010. Macroeconomic Reforms, Government Size, and Investment Behaviour in Nigeria: An Empirical Investigation. Journal of Sustainable Development in Africa, Vol. 12, No. 1.

Vaziri, H., Nademi, Y., Paghe A. A. and Nademi A., 2011. Does Armey Curve Exist in Pakistan and Iran Economies? Journal of Applied Sciences Research, Vol. 7, No. 5, 562 - 565.

Vedder, R. K. and Gallaway, L., 1998. Government Size and Economic Growth. Wahington DC: Joint Economic Committee.

Verma, S. Arora, R., (2010), Does the Indian Economy Support Wagner's Law? An Econometric Analysis, Eurasian Journal of Business and Economics, 3 (5), 77-91.

Yamamura, E., 2008. The Influence of Government Size on Economic Growth and Life Satisfaction. A Case Study from Japan. Unpublished. Munich Personal RePEc Archive Onlinne at http://mpra.ub.uni-muenchari. De/w835/MPRA Paper No. 10835, Posted 29 September, 2008/23:16.

Yamamura, E., 2010. Government Size and Trust. Economics and Econometrics Research Institute Paper Series No. $06 / 2010$

Yuk, W., 2005. Government Size and Economic Growth: Time - Series Evidence for the United Kingdom, 1830 1993. Econometrics Working Paper, EWP0501. 